\title{
Bioplastics: Acceptable for the packaging of organic food? A policy analysis
}

\author{
Ching-Hua Yeh ${ }^{\text {a }}$ \\ Kassel University \\ Friedrich-Karl Lücke ${ }^{b}$ and Johann Janssen ${ }^{b} *$ \\ Fulda University of Applied Sciences
}

\begin{abstract}
Submitted April 27, 2013 / Revised December 9, 2013; January 20, July 11, July 27, and October 23, 2014; and August 16, 2015 / Accepted August 16, 2015 / Published online November 27, 2015

Citation: Yeh, C.-H., Lücke, F.-K., \& Janssen, J. (2015). Bioplastics: Acceptable for the packaging of organic food? A policy analysis. Journal of Agriculture, Food Systems, and Community Development, 6(1), 95-105. http://dx.doi.org/10.5304/jafscd.2015.061.009

Copyright (C) 2015 by New Leaf Associates, Inc.
\end{abstract}

\begin{abstract}
Bioplastics have been introduced as an alternative to petro-based plastics and to provide packaging materials with improved biodegradability and compostability. Over the past few years, several studies have been conducted on bioplastics and their application in global food systems. Although

\footnotetext{
a Department of Organic Agricultural Sciences, Kassel University; 37213 Witzenhausen, Germany.

Ching-Hua Yeh is now at the Institute for Food and

Resource Economics, Rheinische

Friedrich-Wilhelms-Universität Bonn, 53115 Bonn, Germany;

+49-228 73 5963; chinghua.yeh@ill.uni-bonn.de

${ }^{\mathrm{b}}$ Department of Nutritional, Food and Consumer Sciences,

Fulda University of Applied Sciences, 36039 Fulda, Germany

* Corresponding author: Johann Janssen, Department of

Nutritional, Food and Consumer Sciences, Fulda University of

Applied Sciences; 36039 Fulda, Germany;

johann.g.janssen@he.hs-fulda.de
}

the potential environmental benefits have been discussed, little in fact is known about the specific requirements for the application of bioplastics as packaging for organic food.

In this policy brief, we examine the applicability of bioplastics packaging to organic food products, based on the perspectives of interviewed experts in industry and academia. We conclude that international regulations and standards for organic food production should include specifications on the use of bioplastics. This is necessary because consumers expect bioplastics to be an environmentally friendly packaging material. Yet bioplastic packaging remains problematic for producers and consumers of organic food, especially if the raw material is originally sourced from genetically modified plants. There is a need for clarification of the type of raw material that is suitable for use as packaging for organic food. Our findings should enhance 
understanding of the public's expectations and perceptions of bioplastics packaging with regard to environmental impacts and optimized organic food packaging.

\section{Keywords}

bioplastics, polylactic acid (PLA), organic food packaging, genetically modified organism (GMO)

\section{Introduction}

Packaging is an essential part of the food system that connects the product with the consumer (Luning, \& Marcelis, 2009) via the four basic functions of containment, protection, communication, and convenience (Han, 2005; Marsh, \& Bugusu, 2007). Food packaging has evolved in response to patterns of human consumption and changing lifestyles (Risch, 2009). By the late nineteenth century, synthetic polymers had been developed and plastic packaging was introduced. They revolutionized the market for food packaging due to their various desirable features such as plasticity, softness, transparency, flexibility, convenience, protection from oxygen, durability, light weight, and low production cost (Bertolini, 2010; Mahalik \& Nambiar, 2010; Siracusa, Rocculi, Romani, \& Rosa, 2008). The most commonly used plastic materials are polyethylene terephthalate (PET), polyethylene (PE), polypropylene (PP), polyvinyl chloride (PVC), and polystyrene (PS). However, such petrochemical plastics have caused the generation of greenhouse gases (GHG) during manufacturing and waste disposal (Organization for Economic Co-operation and Development [OECD], 2011b; Siracusa et al., 2008). It was estimated that, roughly 10 million plastic cups, 1 billion plastic bottles, and 10 billion plastic bags are thrown away each day (OECD, 2011b). The global consumption of conventional petrochemical plastics exceeds 200 million metric tons, with an annual growth rate of approximately $5 \%$, which means a significant depletion of mineral oil resources (Siracusa et al., 2008). Consequently, innovative packaging technology was developed to attempt to improve packaging materials in order to minimize the use of resources and production costs, while simultaneously improving quality and safety (Han, 2005). Later on, plastic packaging became recyclable on an industrial scale; furthermore, plastic materials derived from renewable resources were developed, which are known as bioplastics, which are aimed to be biodegradable and compostable (Tharanathan, 2003).

\section{Bioplastics}

Bioplastics have been developed to be recyclable numerous times through natural or technical systems, with the goals of saving mineral oil and providing an alternative to petro-based plastics. Bioplastics create potential for composting as an alternative to waste disposal. This reduces the amount of conventional plastics accumulating in landfills and minimizes the amount of toxic substances released into the environment (Bertolini, 2010; Callister \& Rethwisch, 2010). It is especially important for bioplastics to be compostable in consideration of the littering behavior in some countries. Moreover, it has been found by many researchers (Piemonte \& Gironi, 2011; Ren, 2010; Singh, 2011; Vink, Glassner, Kolstad, Wooley, \& O'Connor, 2007) that the use of bioplastics substantially reduce $\mathrm{CO}_{2}$ emissions by achieving carbon neutrality.

As a type of food packaging, many bioplastics have low oxygen permeability, which makes them effective for packing fresh fruit and vegetables. The disadvantages of bioplastics include limited mechanical stability with high brittleness, and high moisture permeability that leads to a shorter shelf life when the food is exposed to a humid and high-temperature environment.

The prefix "bio-" of bioplastics catches the public's attention and suggests a high level of sustainability and environmental protection. In European countries, this prefix often refers to any agricultural products produced using organic production standards. ${ }^{1}$ Hence the term "bioplastics" may imply, particularly to German consumers, that the

\footnotetext{
1 The organic production standard is applied in organic farming. It involves the use of organic fertilizers, without chemical substances, rather than synthetic fertilizers. Additionally, methods of biological and mechanical pest management and crop rotation are used in organic farming instead of the application of synthetic pesticides and herbicides as used in conventional farming (Greene, 2007; IFOAM, 2012).
} 
material has also been produced according to the same organic production regulations. However, "bio-" here is not in the sense of "certified organic," but stands for the two concepts of being bio-based and biodegradable (Beier, 2009). The European Bioplastics Association provides a brief definition: "Bioplastics are commonly defined as plastics that are biobased, biodegradable or both" (European Bioplastics Association, 2011a, p. 3).

The primary objective of this present policy analysis is to consider whether the current and possible future use of bioplastics really conforms to the expectations of manufacturers and consumers of organic food. ${ }^{2}$ We therefore use a key informant approach to gain an understanding of the stakeholder perspective in the food industry with regard to bioplastic packaging for organic food. Finally, the current situation regarding the sustainability of bioplastics packaging for organic food is discussed, particularly the environmental impact.

\section{Methods}

This policy analysis employs a qualitative research approach. Our data gathering included two main phases. Firstly, current organic production regulations and standards in Europe, the United States, and Japan are reviewed and compared. The analysis of regulations and standards are concentrated on the up-to-date amended version of the respective regulation and standard that has been available since 2012. We studied the sections on organic food production and processing in the regulations and standards, with a focus on the manner of genetic modification, and particularly the issue of organic food packaging. By initially conducting an intensive secondary data review, we developed interview questions that considered the requirements for organic food backpacking, the dimen-

\footnotetext{
2 Organic food is produced through organic farming products, based on the IFOAM principles of agriculture (IFOAM, 2012). In recent years, several studies (Canavari \& Olson, 2007; Kristiansen, Taji, \& Reganold, 2006; Oughton \& Ritson, 2007; Zanoli, Gambelli, \& Vairo, 2012) have indicated that the top three reasons for purchasing organic food are: (1) one's own health and safety; (2) environmental protection, meaning production and processing that prohibit genetically modified organisms (GMO) in farming and genetically modified (GM)-based food production; and (3) better tasting produce.
}

sions extended from the use of bioplastics for organic foods, and consumer perspectives on bioplastics generally as well as on the acceptability and understandability with respect to the application of bioplastic packaging for organic food.

Secondly, qualitative data were collected through key informant interviews with an array of food experts in four countries, in order to explore their opinions on public understanding of bioplastic packaging and to identify disparities between perceptions and reality.

\section{Respondents and Data Collection}

The second phase of the qualitative approach, interviews with experts, was conducted to provide comprehensiveness and to consider the feasibility and applicability of bioplastics usage in the organic food sector. Due to geographic issues and location, expert interviews were conducted in English, individually and face-to-face where possible and practical, or otherwise by Internet phone and webcam. The length of each interview was approximately 60 minutes and was audiorecorded and later fully transcribed. The interview questions were cognitively examined and pretested initially by our first interviewee, a food packaging scientist whose work is devoted to the food packaging industry, in order to ensure their understandability and practicability by respondents.

Altogether, 10 key informants were recruited. Two key informants are staff at bioplastics producers based in the United Kingdom and Germany, both of which operate worldwide, as well as in the U.S. Two are organic food producers from Germany, and the remaining informants include one quality-oriented German food retailer, one European food law consultant located in Belgium, and four food scientists and researchers in food processing and food packaging organizations, from Austria and Germany. Interviewees were selected according to their background, profession, and work experience in the food or food packaging industry. One Japanese bioplastics producer we approached declined to be interviewed, unfortunately, but instead provided useful information and documents about Japanese regulations on organic food packaging. With the personal experiences and knowledge of these key informants, our 
approach should provide new insights into stakeholders' opinions. Even though the selection and sample size are small, we believe it is sufficient to complete our analysis because of the diverse background of our participants, who represent stakeholders of the supply chain and have substantial experience and knowledge.

\section{Data Analysis}

After the interviews were completed, content analysis was conducted to identify essential information from the interview data. Responses from the experts were categorized into characteristics and consequences and analyzed in order to develop a meaningful interpretation of all individually stated concepts; the data were then coded into broader categories.

\section{Major Themes in Bioplastics: Consumer Expectations and Reality}

The main themes from our key informant interviewing data related to the understanding of bioplastics are summarized below. Some of the opinions are reflective of previous studies.

\section{Misleading Statement of "GMO Free" for PLA Bioplastics}

Within the bioplastics group, polylactic acid (PLA) bioplastics have the greatest market share and are also the most prominent thermoplastic derived from agricultural crops (Ren, 2010). PLA is produced through the bacterial fermentation of hydrolyzed corn starch, followed by the polymerization of lactic acid (Bund Ökologische Lebensmittelwirtschaft [BÖLW], 2011; Ren, 2010). Globally, the largest PLA producer has an annual production capacity of around 140,000 metric tons (NatureWorks, 2009). One key informant from a bioplastics manufacturer reported that raw material for the PLA production of this large bioplastic producer is derived from renewable resources and is a mixture of genetically modified (GM) and conventional field corns. Due to the intense heat applied during the manufacturing process, the PLA resin ultimately used in the production of bioplastics does not contain any GMOs, nor does it have a detectable modified gene remaining. Therefore, the PLA has a GMO-free certification, according to U.S. legislation declaring its GM-free identity.

However, contrary positions are apparent regarding perceptions of the "GMO free" label for PLA. According to our interviewees, organic producers' and consumers' perceptions of the "GMO-free" designation are that the overall supply chain for the item's production entails no genetically modified material, all the way from the field to the consumer. This is in contrast to the bioplastics producer's point of view that PLA has a GMO-free identity. The main reason for this view is that the product no longer contains recombinant DNA after processing and is essentially equivalent to PLA from non-GMO sources. This has been disputed, however, by stakeholders of organic food production and processes. One interviewee who is an organic food producer believes that the name "bioplastics" is misleading to consumers if the material is derived from raw material containing a GMO. From this point of view, "bioplastics" should not be labeled as "GMO-free." These stakeholders believe that consumers will not be able to understand the differences between products containing recombinant DNA and products which have been prepared from GMO-containing source material, while no longer containing recombinant DNA.

\section{Lack of Packaging Specifications in Organic Production Regulation}

In recent years, many food producers and processors have adopted bioplastics as packaging materials. This is not only due to their specific properties; it is also used as a marketing tool to address and draw attention to the benefits of biodegradability and compostability. Hence these potential environmental benefits are expected by consumers (Kale, Kijchavengkul, Auras, Rubino, Selke, \& Singh, 2007). However, our interviewed experts also mention that, beyond the bioplastics producers, there is a lack of knowledge about the application and acceptability of bioplastics for packaging organic foods in terms of the specific requirements of the organic food sector. Currently the use of bioplastics packaging for organic food is allowed in the European Union since there is no restriction in EU Regulation (EC) No. 834/2007 (European Commission, 2007) that prevents the 
use of bioplastics packaging, as long as it fulfills the general safety requirements.

As far as the common element of international and national organic production regulations and standards, GMOs are only forbidden for use in "food." In particular, the ban on GMOs in organic production regulations refers only to "organic farming" or "organic food production," which does not mention packaging in the legal standards on organic food, as listed in Figure 1. For example, the International Federation of Organic Agriculture Movements Basic Standards (IFOAM, 2012) and EU Regulation (EC) No. 834/2007 (European Commission, 2007) state that genetic engineering and GMOs are incompatible with the concept of organic production. Yet no specific requirements are mentioned for organic food packaging. Only three private organic production standards were found to contain specific requirements for organic food packaging materials: Naturland standards, Demeter standards, and the UK Soil Association standards (Figure 1).

In our interviews, the industry experts stated that, from the perspective of organic producers and processors, the GM-sourced bioplastic packaging is not suitable for their organic food products. This is mainly due to the fact that bioplastics producers do not reveal whether the raw material for bioplastics is derived from GM-based plants or from conventional ones, nevertheless, the end product of bioplastic packaging is detected GMfree after high-heat process. In addition, consumers may not accept the production of bioplastics that involves the use of agricultural commodities of GM origin (Ahvenainen, 2003). Gaskell et al. (2006) concluded that there is still a lack of acceptance by EU consumers for using GM plants even for nonfood material, since GMOs are a comparatively important issue in European countries. Their possible negative environmental impacts conflict with the concept of organic agriculture (Gaskell et al., 2006).

\section{Impacts of GM-Based Bioplastic Raw-Material Extraction in Bioplastic Production}

Presently, the global production capacity of bioplastics derived from renewable resources is estimated at approximately 1 million metric tons annually (Goodall, 2011). This production capacity is based on 300,000 hectares (740,000 acres) of agricultural crops used to produce bioplastics, which is roughly $0.02 \%$ of the global total of naturally irrigated arable land (Goodall, 2011). In 2010, commercial bioplastics production for the European market reached between 100,000 and 150,000 metric tons, which is equivalent to around 75,000 hectares $(185,000$ acres $)$ cropped today. This figure will grow continually to a projected maximum of 1.25 million hectares $(3,089,000$ acres $)$ or approximately 0.7 percent of available agricultural land, if 2.5 million metric tons of bioplastics are expected to be used in Europe by 2020 (European Bioplastics Association, 2011a). As the data shows, the area of land used for bioplastics is relatively small, compared to the global amount of cultivated land. Therefore increasing the usage of farmland for producing bioplastics may not be seen as a threat, since, for the time being, the quantity of bioplastic production has not reached an economies-of-scale supply level worldwide. However, our interviewed experts, in addition to the experts from bioplastic producers, stated that it is important to consider the conflict between the value of crops for human food consumption and industrial use as manufacturing feedstock.

Moreover, the arguments against GMO crops as raw materials for bioplastics persist. The cultivation of GMO crops may have various advantages, such as higher yields, pest resistance, drought improvement, and salt stress tolerance (Kotchoni, Gachomo, \& Mwangi, 2005). However, whether a higher salt stress tolerance really works on a commercial scale remains to be seen. On the other hand, possible undesirable effects include risks to human and animal health. There may also be negative effects on biodiversity and the environment, such as accelerating the depletion of natural resources, and increased soil erosion due to the conversion of rainforest ecosystems into crop land or pastures (Rosset, 2006; European Bioplastics Association, 2011a), as well as the toxicity to nontarget species and the uncontrolled spread of resistant weeds and pests (Carter, Moschini, \& Sheldon, 2011). 


\begin{tabular}{|c|c|c|c|}
\hline \multirow{4}{*}{ 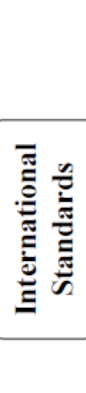 } & & $\begin{array}{l}\text { GMO concerns with organic food production } \\
\text { (General specification on food product itself) }\end{array}$ & $\begin{array}{l}\text { Packaging materials associated with GMO concerns } \\
\text { in organic food production }\end{array}$ \\
\hline & $\begin{array}{l}\text { IFOAM Basic } \\
\text { Standards }\end{array}$ & $\begin{array}{l}\text { - "Organic management system do not use genetically modified organism } \\
\text { (GMO) or their derivatives, except vaccines, in all of organic production and } \\
\text { processing (IFOAM, 2012, p. 17)" }\end{array}$ & No specification on packaging materials with respect to GMO is included. \\
\hline & $\begin{array}{c}\text { Codex } \\
\text { Alimentarius }\end{array}$ & $\begin{array}{l}\text { - “...genetically engineered/modified organisms }(G E O / G M O) \text { are not } \\
\text { compatible with the principles of organic production...(Codex Alimentarius } \\
\text { Commission, 1999, p. 3)" }\end{array}$ & No specification on packaging materials with respect to GMO is included. \\
\hline & $\begin{array}{l}\text { EU Regulation } \\
\text { (EC) No } \\
\mathbf{8 3 4 / 2 0 0 7}\end{array}$ & $\begin{array}{l}\text { - "Genetically modified organisms (GMOs) and products produced from or by } \\
\text { GMOs are incompatible with the concept of organic production and } \\
\text { consumers' perception of organic products. (European Commission, 2007, p. } \\
\text { L189/2)" }\end{array}$ & No specification on packaging materials with respect to $\mathrm{GMO}$ is included. \\
\hline \multirow{3}{*}{ ב气 } & $\begin{array}{c}\text { NOP } \\
\text { Standards (US) }\end{array}$ & $\begin{array}{l}\text { - "...genetically modify organisms or influence their growth and development } \\
\text { by means that are not possible under natural conditions or processes and are } \\
\text { not considered compatible with organic production. (USDA, 2013)" }\end{array}$ & No specification on packaging materials with respect to GMO is included. \\
\hline & JAS Standards & $\begin{array}{l}\text { - "The criteria of the production methods for plant products are ...processing } \\
\text { and produced without recombinant DNA technology ...(MAFF, 2005b, p.1-3)" }\end{array}$ & No specification on packaging materials with respect to $G M O$ is included. \\
\hline & $\begin{array}{l}\text { Naturland } \\
\text { Standards } \\
\text { (Germany) }\end{array}$ & $\begin{array}{l}\text { - "Products that are produced in compliance with Naturland standards must be } \\
\text { made without the employment of genetically modified organisms (GMO) } \\
\text { and/or GMO derivatives. (Naturland, 2013, p. 10)" }\end{array}$ & $\begin{array}{l}\text { - "The use of bioplastics is recommended. However, in this case genetically } \\
\text { modified raw materials may not be used in their manufacture. Proof is to be } \\
\text { provided by the packaging manufacturer or of the supplier in the form of a } \\
\text { written declaration submitted during organic inspection that no genetically } \\
\text { modified organisms (GMOs) and their derivatives were used. (Naturland, } \\
2013, \text { p. 12) }\end{array}$ \\
\hline \multirow{5}{*}{ 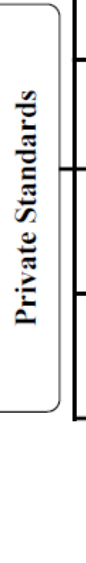 } & $\begin{array}{l}\text { Demeter Standards } \\
\text { (Germany) }\end{array}$ & $\begin{array}{l}\text { - "Procedures expresslz prohibited on DEMETER products....that result from } \\
\text { genetically manipulated organisms or from derivtives of such organisms } \\
\text { (Demeter, 2013, p. 10)" }\end{array}$ & $\begin{array}{l}\text { - "Allowed Materials:...Lactic Acid (From fermentation of a GMO free } \\
\text { carbohydrate substrate only) (Demeter, 2013, p. 71)" }\end{array}$ \\
\hline & $\begin{array}{l}\text { Bioland Standards } \\
\text { (Germany) }\end{array}$ & $\begin{array}{l}\text { - "Products produced according to BIOLAND standards, have to be produced } \\
\text { without the use of genetically modified organisms (GMOs) and/or GMO } \\
\text { derivatives (Bioland, 2015, p. 2)" }\end{array}$ & No specification on packaging materials with respect to $\mathrm{GMO}$ is included. \\
\hline & $\begin{array}{l}\text { Bio Suisse } \\
\text { Standards } \\
\text { (Switzerland) }\end{array}$ & $\begin{array}{l}\text { "No use of genetic engineering ... from genetic manipulation and from the use } \\
\text { of genetically modified organisms (GMOs) and their derivatives. (Bio Suisse, } \\
2012, \text { p. 7)" }\end{array}$ & No specification on packaging materials with respect to GMO is included. \\
\hline & $\begin{array}{l}\text { Soil Association } \\
\text { Standards (UK) }\end{array}$ & $\begin{array}{l}\text { - “...must not use genetically modified organisms (GMOs) in organic food } \\
\text { processing. They do not fit with the principles of organic agriculture...(Soil } \\
\text { Association, 2011, p. 33)" }\end{array}$ & $\begin{array}{l}\text { - "You must not use these materials in your packaging: ... that contain, have } \\
\text { been derived from, or manufactured using, genetically modified organisms or } \\
\text { genetically engineered enzymes. (Soil Association, 2013, p. 63)" }\end{array}$ \\
\hline & & & $\begin{array}{l}\text { - "For any compostable or biodegradable primary packaging...these materials } \\
\text { are often derived from genetically modified organisms or use genetically } \\
\text { engineered enzymes in their manufacture....is not permitted. (Soil } \\
\text { Association. 2013, p. 64)" }\end{array}$ \\
\hline
\end{tabular}

Sources: Based on Bio Suisse, 2012; Bioland, 2015; Codex Alimentarius Commission, 1999; Demeter 2013; European Commission, 2007; IFOAM 2012; Ministry of Agriculture, Forestry and Fisheries [MAFF], 2005a, 2005b; Naturland, 2013; Soil Association, 2013; U.S. Government Printing Office [GPO], n.d. 


\section{Consumer Confusion about Bioplastics}

Our interviewees who come from the scientific field also mention that in Germany and other European countries, the prefix "bio-" normally refers to any agricultural products produced according to organic standards by certified farms and processing plants. The term "bioplastics" may suggest, especially to German consumers, that this material has been produced according to these standards, which is normally not the case. Bioplastics neither come from organic-certified agricultural production, nor are they certified as organic. Secondly, the terms "compostable" and "biodegradable" for bioplastics may be confusing to consumers, leading them to believe that bioplastics packaging will rapidly "disappear" after being littered (Mojo, 2007). Such misconceptions about bioplastics may lead to inappropriate disposal and indirectly increase littering.

\section{The Myth of Life Cycle Assessment (LCA) on Bioplastics}

To evaluate the sustainability and environmental friendliness of production methods and products, a life cycle assessment (LCA) has been used globally since 1990 (Mattsson \& Sonesson, 2003). LCA is conducted to evaluate a product or a process by covering all stages throughout its life span, from primary production to end-of-life disposal. The interviewed scientific experts remarked that LCA studies may indicate that bioplastics could be superior to plastics made from fossil carbon in terms of reducing GHG emissions. This is mainly due to carbon being used in bioplastics production, which comes from $\mathrm{CO}_{2}$ assimilated by crop plants. However, the application of LCA considers not only carbon measures, but also many other measures, such as energy, water usage, etc. Such remarks have been adequately reflected in the findings of Auras, Lim, Selke, \& Tsuji (2010).

\section{Discussion and Recommendations}

\section{Harmonization of Regulations and Standards for the Packaging of Organic Food \\ Organic food is produced according to the principles of natural and ecological methods (Courville, 2006; Kristiansen et al., 2006).}

Kristiansen et al. (2006) suggest that the main reason for prohibiting the use of GMOs is potentially irreversible processes with potentially negative effects on future generations and the ecosystem. As previously mentioned, official regulations on organic food production currently do not contain specific requirements or "positive lists" for packaging material, and few private organic organizations prohibit the use of bioplastics packaging derived from raw materials containing GMO, or processed with the involvement of GMO. Therefore there is a need for common regulations on organic food packaging. On the basis of our study, we suggest that such regulations ensure that no GMO is used in raw materials or in starch fermentation during the production of bioplastics.

Any revision of existing regulations for the use of bioplastics should consider the potential migration of material from GMO into food. For example, EU Regulation (EC) No. 10/2011 (European Commission, 2011) on plastic materials and articles intended for contact with food already covers several natural materials, such as starch and cellulose, that are used in bioplastics production, but does not yet address the GMO origin of food contact materials.

\section{Correct End-of-Life Disposal for Bioplastics}

It is important to inform consumers of how to properly dispose of packages made from bioplastics. A good example of the commercial application of bioplastic packaging was one yogurt brand (ACTIVIA), produced by Danone GmbH, that had been packaged in PLA cups produced by NatureWorks LLC. The PLA cups used to package yogurt are derived from a combination of GM and conventional corn cropped in the United States. However, as is common in yogurt packaging, the yogurt lid was made from non-biodegradable materials. Logically, the empty yogurt cup and lid should be disposed of in separate bins. However, many consumers may not do this due to the inconvenience such a disposal procedure, or they may simply not know the difference. Moreover, the composting of PLA bioplastics is only feasible at industrial composting facilities, not in households. In practice, PLA cups are not sorted out and recycled but incinerated (Deutsche Umwelthilfe, 
2011). Therefore it is critical to inform the general public about the proper steps in disposing of packaging after food consumption, and the disposal of bioplastics should be further developed and optimized. This scenario confirms Beier's argument (2009) that there is no scientific evidence of PLA bioplastics being more environmentally friendly than petrochemically derived plastics in practice. Hence, at the end of 2011 the German Environmental Aid Association, Deutsche Umwelthilfe e.V. (DUH), launched a campaign criticizing statements on sustainability made in the advertisements for this yogurt brand (Deutsche Umwelthilfe, 2011). The manufacturer subsequently made changes to the advertisements. Any claims that bioplastics packaging is superior to alternatives by being more environmentally friendly should cease, as long as there is no credible scientific evidence to support this claim.

\section{Proper Life Cycle Assessment for Bioplastics}

There are many other issues that need to be considered when conducting LCA of bioplastic production. These issues include the consumption of nonrenewable resources and the impact on various areas such as biodiversity, climate, the nutrient balance of soil and water, and the health of humans, animals, and plants (Beier, 2009). Corn is presently the dominant crop for PLA manufacturing in the United States (Deutsche Umwelthilfe, 2011). Auras et al. (2010) pointed out that corn cultivation contributes markedly to eutrophication, soil acidification, and nitrate leaching. Specifically, monoculturing with the extensive use of fertilizers may reduce biodiversity and jeopardize natural resources. Moreover, eco-efficiency instruments may also be applied to examine the environmental impact of bioplastics. These include measuring GHG emissions, land space usage for crops, water utilization, and the generation of environmental toxicants.

\section{Researching Alternative Raw Material for Bioplastics}

The world's population is projected to reach 9.1 billion by 2050 (OECD, 2011a), and the production of both food and nonfood items, such as biomaterials and bioenergy, will put pressure on the agricultural system to meet consumer demand.
Bioplastics are made from agricultural raw materials such as corn or starchy plants, which can also be consumed as human food. Hence it is highly desirable to find alternative raw materials to replace food crops for bioplastics manufacturing in the future. At present, there are various plant-based types of bioplastics that are readily available in the market, including cellulosic materials and biomass byproducts that do not compete with food production.

In addition, to foster the environmental superiority of bioplastics, efficient technology for increasing their production scale should be adopted, and the design of bioplastics packaging should be optimized to allow multiple uses (Beier, 2009; BÖLW, 2011; European Bioplastics Association, 2008).

\section{Conclusions}

The use of bioplastics is a valuable approach to sustainability in the packaging sector of the global food system. It aims to bring positive changes by reducing the use of energy and natural resource consumption and by generating less waste. This is in line with the principles of organic food production. Hence bioplastics attract considerable interest in research and development projects in academic institutions and industry. However, the terms "compostable," "biodegradable," and "from renewable resources" used for describing bioplastics do not necessarily reflect maximum environmental friendliness or the overall sustainability of food systems, especially when the use of GMOs for production of bioplastics is taken into account. When considering the compatibility between organic food and bioplastics packaging, it is necessary to take a critical look at the various controversial issues.

Consumers of organic food are likely to expect that the packaging of organic food to be produced from environmentally and socially acceptable raw materials, and that the packaging be recyclable or compostable. However, small and medium-sized food producers face problems in selecting suitable bio-based solutions for food packaging from the abundance of available raw materials and processed materials. This situation contributes to the persistent dominance of conventional plastics in the market. 
In 2015, the Association of Organic Food Producers (AoeL, Assoziation Oekologischer Lebensmittelhersteller e.V.) in Germany developed an Internet tool called "Biokunststoff-Tool" (AoeL, 2015) that serves as a decision-making solution for food producers dealing with bioplastic and other packaging. The system gathers information on existing bioplastics variants in the areas of ecology, social acceptability, safety, quality, and technology. It focuses on key aspects such as avoiding food competition at the origin of bioplastic raw material, GM-free raw materials sourcing, and environmentally friendly packaging production. Food producers then can base their selection of packaging material and technology not only on the physical properties of the packaging, but also on the environmentally and socially responsible production methods used in these packaging materials.

Further research on the topic of bioplastics should address several issues. First, the development of sustainability parameters with predefined specifications (from field plant to composted soil) will help policy-makers and food producers prioritize targets appropriately within the dilemmas of our food system. Second, it is advisable to broaden and deepen insight into the sustainability issues of bioplastics by enlarging the sample size of stakeholders used in research. With regard to policy recommendations we first recommended that, in line with consumer expectations, a ban on GMO usage in organic food packaging is needed and should be clearly specified in the regulations. The second objective should be the replacement of corn (both GMO and conventional) in bioplastics manufacturing with agricultural and forestry byproducts and food waste. Third, clear instructions to consumers should enable them to dispose of this kind of packaging appropriately.

Finally, there needs to be a compromise between legislative bodies and organic food stakeholders. Both parties need to reach a win-win agreement that will benefit all stakeholders along the value chain. This is a substantial challenge, but nevertheless we should not ignore this serious debate concerning the future of our food system. Flexibility on any future changes and developments in bioplastics packaging regulations should be maintained, because imposing additional regula- tions and restrictions on bioplastics could hamper its development. It is essential to remain positive and open to the development of bioplastics, as well as to welcome future innovations from advanced technology research in bioplastics packaging.

\section{References}

Ahvenainen R. (Ed.). (2003). Novel food packaging techniques. Boca Raton, Florida: CRC Press.

AoeL. (2015). Biokunststoff-Tool. http://www.aoel.org

Auras, R., Lim, L.-T., Selke, S. E. M., \& Tsuji, H. (Eds.). (2010). Poly(lactic acid): Synthesis, structures, properties, processing, and applications. Hoboken, New Jersey: John Wiley \& Sons.

Beier, W. (2009). Biologisch Abbaubare Kunststoffe. Dessau-Rosslau, Germany: Umweltbundesamt Pressestelle. Retrieved from http://www.umweltbundesamt.de/sites/default/ files/medien/publikation/long/3834.pdf

Bertolini, A. C. (Ed.). (2010). Starches: Characterization, properties, and applications. Boca Raton, Florida: CRC Press.

Bio Suisse. (2012). Bio Suisse standard for the production, processing and marketing of bud produce from organic farming. Basel: Bio Suisse. Retrieved from http://www.bio-suisse.ch/media/en/pdf2012/ rl 2012 e.pdf

Bioland. (2015). Bioland standards. Retrieved from http://www.bioland.de/fileadmin/dateien/HP Dokumente/Richtlinien/Bioland Standards 2015-03-23.pdf

Bund Ökologische Lebensmittelwirtschaft [BÖLW]. (2011). Nachbaltige Verpackung von Bio-Lebensmitteln: Ein Leitfaden für Unternehmen. Berlin: Author.

Callister, W. D., Jr., \& Rethwisch, D. G. (2010). Materials science and engineering: An introduction. New York: John Wiley \& Sons.

Canavari, M., \& Olson, K. D. (Eds.). (2007). Organic food: Consumers' choices and farmers' opportunities. Heidelberg, Germany: Springer.

Carter, C. A., Moschini, G., \& Sheldon, I. (Eds.). (2011). Genetically modified food and global welfare. London: Emerald Group.

Codex Alimentarius Commission. (1999). Guidelines for the production, processing, labelling and marketing of organically produced foods (GL 32-1999). Retrieved from https://www.codexalimentarius.org/input/ download/standards/360/cxg 032e.pdf 
Courville, S. (2006). Organic standards and certification. In P. Kristiansen, A. Taji, \& J. Reganold (Eds.), Organic agriculture: A global perspective (pp. 201-219). Collingwood, Australia: CSIRO Publishing.

Demeter. (2013). Processing standards for the use of Demeter,

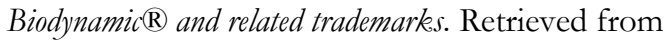
http://www.biodynamic.org.nz/wp-content/ uploads/2015/02/DI processing-stds-DemeterBiodynamic-14-e.pdf

Deutsche Umwelthilfe. (2011). Danone verpacket Activia-Jogburt weiterbin in Bechern aus genmanipulierten Maispflanzen. Retrieved from http://www.duh.de/ pressemitteilung.html? \&tx ttnews[tt news] $=2748$

European Bioplastics Association. (2008). Life cycle assessment of bioplastics. Retrieved from http://en.european-bioplastics.org/wp-content/ uploads/2011/04/pp/LCA PositionsPaper.pdf

European Bioplastics Association. (2011a). Frequently asked questions on the use of agricultural resources for bioplastics production. Retrieved from http://en.european-bioplastics.org/wp-content/ uploads/2011/04/FAQ/FAQ_Agri_web.pdf

European Commission. (2007). Council regulation (EC) No 834/2007 of 28 June 2007 on organic production and labelling of organic products and repealing Regulation (EEC) No 2092/91. Official Journal of the European Union, L189, 1-23. Retrieved from http://eur-lex.europa.eu/legal-content/EN/ TXT/PDF/?uri=CELEX:32007R0834\&from=EN

European Commission. (2011). Commission regulation (EU) No 10/2011 of 14 January 2011 on plastic materials and articles intended to come into contact with food. Official Journal of European Union, L 12, 1-89. http://eur-lex.europa.eu/legal-content/ EN/TXT/PDF/?uri=CELEX:32011R0010\&from $=\mathrm{EN}$

Gaskell, G., Allansdottir, A., Allum, N., Corchero, C., Fischler, C., Hampel, J., Jackson, J., Kronberger, N., Mejlgaard, N., Revuelta, G., Schreiner, C., Stares, S., Torgersen, H., \& Wagner, W. (2006). Europeans and biotechnology in 2005: Patterns and trends, Eurobarometer 64.3. Retrieved from the European Commission's Directorate-General for Research website: http://ec.europa.eu/research/press/2006/pdf/ pr1906 eb 643 final report-may2006 en.pdf

Goodall, C. (2011). Bioplastics: An important component of global sustainability. Biome Bioplastics Retrieved from the Carbon Commentary website: https://emf-packs.s3-eu-west-1.amazonaws.com/ Act $\% 202 \% 20$ Additional $\% 20$ Resources/Act.2. White\%20paper Biome\%20bioplasticsdoc.pdf

Greene, C. (2007). An overview of organic agriculture in the United States. In M. Canavari \& K. D. Olson (Eds.), Organic food: Consumers' choices and farmers' opportunities (pp. 17-29). Heidelberg, Germany: Springer.

Han, J. H., (Ed.). (2005). Innovations in food packaging. San Diego, California: Elsevier.

International Federation of Organic Agriculture Movements [IFOAM]. (2012). The IFOAM norms for organic production and processing, version 2012. Retrieved from http://www.ifoam.org/sites/default/files/ page/files/ifoam_norms_version_august_2012_ with cover 0.pdf

Kale, G., Kijchavengkul, T., Auras, R., Rubino, M., Selke, S. E., \& Singh, S. P. (2007). Compostability of bioplastic packaging materials: An overview. Macromolecular Bioscience, 7(3), 255-277. http://dx.doi.org/10.1002/mabi.200600168

Kristiansen, P., Taji, A., \& Reganold, J. (Eds.). (2006). Organic agriculture: A global perspective. Collingwood, Australia: CSIRO Publishing.

Luning, P. A., \& Marcelis, W. J. (2009). Food quality management: Technological and managerial principles and practices. Wageningen, Netherlands: Academic Publishers. http://dx.doi.org/10.3920/978-90-8686-116-3

Mahalik, N. P., \& Nambiar, A. N. (2010). Trends in food packaging and manufacturing systems and technology. Trends in Food Science \& Technology, 21(3), 117-128. http://dx.doi.org/10.1016/j.tifs.2009.12.006

Mattsson, B., \& Sonesson, U. (2003). Environmentally-friendly food processing. Abington, UK: Woodhead Publishing.

Marsh, K., \& Bugusu, B. (2007). Food packagingRoles, materials, and environmental issues. Journal of Food Science, 72(3), R39-R55. http://dx.doi.org/ 10.1111/j.1750-3841.2007.00301.x

Ministry of Agriculture, Forestry and Fisheries [MAFF]. (2005a). Japanese agricultural standard for organic processed foods (Notification No. 1606 of the Ministry of Agriculture, Forestry and Fisheries of October 27, 2005). Retrieved from http://www.maff.go.jp/e/jas/specific/pdf/ $\underline{834 \text { 2012-3.pdf }}$ 
MAFF. (2005b). Japanese agricultural standard for organic plants (Notification No. 1605 of the Ministry of Agriculture, Forestry and Fisheries of October 27, 2005). Retrieved from http://www.maff.go.jp/e/jas/specific/pdf/ 833 2012-3.pdf

Mojo, S. (2007). Compostable products: Designing for disposal. Journal of Polymers and the Environment, 15(4), 289-294. http://dx.doi.org/10.1007/s10924-007-0073-4

NatureWorks. (2009). The Ingeo ${ }^{T M}$ journey. Retrieved from http://www.natureworksllc.com/ /media/News and Events/NatureWorks TheIngeoJourney pdf. pdf

Naturland (2013). Naturland standards on production. Gräfelfing, Germany: Author. Retrieved from http://www.naturland.de/fileadmin/MDB/ documents/Richtlinien englisch/NaturlandStandards-on-Production.pdf

Organization for Economic Co-operation and Development [OECD]. (2011a). Challenges for agricultural research. Paris: OECD Publishing. http://dx.doi.org/10.1787/9789264090101-en

OECD. (2011b). Future prospects for industrial biotechnology. Paris: OECD Publishing. http://dx.doi.org/10.1787/9789264126633-en

Oughton, E., \& Ritson, C. (2007). Food consumers and organic agriculture. In J. Cooper, C. Leifert, \& U. Niggli (Eds.), Handbook of organic food safety and quality (pp. 74-94). Boca Raton, Florida: CRC Press. http://dx.doi.org/10.1533/9781845693411.1.74

Piemonte, V., \& Gironi, F. (2011). Land-use change emissions: How green are the bioplastics? Environmental Progress \& Sustainable Energy, 30(4), 685-691. http://dx.doi.org/10.1002/ep.10518

Ren, J. (2010). Biodegradable poly (lactic acid): Synthesis, modification, processing and applications. Heidelberg, Germany: Springer.

Risch, S. J. (2009). Food packaging history and innovations. Journal of Agricultural and Food Chemistry, 57(18), 8089-8092. http://dx.doi.org/10.1021/if900040r
Rosset, P. M. (2006). Genetically modified crops for a hungry world: How useful are they really? Tailoring Biotechnologies, 2(1), 79-94.

Kotchoni, O. S., Gachomo, E. W., \& Mwangi, M. (2005). Commercial production of genetically modified crops: A prognosis towards global acceptance. International Journal of Agriculture \& Biology, 7, 681-688.

Singh, R. (2011). Facts, growth, and opportunities in industrial biotechnology. Organic, Process Research \& Development, 15(1), 175-179. http://dx.doi.org/10.1021/op100312a

Siracusa, V., Rocculi, P., Romani, S., \& Rosa, M. D. (2008). Biodegradable polymers for food packaging: A review. Trends in Food Science \& Technology, 19(12), 634-643. http://dx.doi.org/10.1016/j.tifs.2008.07.003

Soil Association. (2013). Soil Association organic standards: Food and drink (Revision 17.0). Retrieved from http://www.soilassociation.org/LinkClick.aspx?file ticket $=41 \mathrm{KnBZAUtQs} \% 3 \mathrm{~d} \& \mathrm{tabid}=353$

Tharanathan, R. N. (2003). Biodegradable films and composite coating: Past, present and future. Trends in Food Science \& Technology, 14(3), 71-78. http://dx.doi.org/10.1016/S0924-2244(02)00280-7

U.S. Government Printing Office [GPO]. (n.d.). Electronic Code of Federal Regulations: National Organic Program, $\int$ 205.2, Subpart A-Definitions. Retrieved from http://www.ecfr.gov/cgi-bin/text-idx?SID= $34 \mathrm{f} 6 \mathrm{~b} 88 \mathrm{eb} 2 \mathrm{a} 13 \mathrm{cf0c} 21 \mathrm{ab} 5 \mathrm{a} 1 \mathrm{~b} 8 \mathrm{c} 1917 \mathrm{c} \&$ node $=\mathrm{se} 7.3$. $20512 \& \mathrm{rgn}=\operatorname{div} 8$

Vink, E. T. H., Glassner, D. A., Kolstad, J. J., Wooley, R. J., \& O'Connor, R. P. (2007). Original research: The eco-profiles for current and near-future NatureWorks ${ }^{\circledR}$ polylactide (PLA) production. Industrial Biotechnology, 3(1), 58-81. http://dx.doi.org/10.1089/ind.2007.3.058

Zanoli, R., Gambelli, D., \& Vairo, D. (2012). Scenarios of the organic food market in Europe. Journal of Food Policy, 37(1), 41-57. http://dx.doi.org/10.1016/i.foodpol.2011.10.003 